\title{
Distillers feeds from various grains as protein sources for pigs
}

\author{
MATTI NÄSI \\ Department of Animal Husbandry, University of Helsinki, \\ SF-00710 HELSINKI, Finland
}

\begin{abstract}
The nutrient digestibility and protein utilization of distillery feeds derived from dehulled barley, rye and wheat were studied with growing pigs receiving one of eleven diets in which the protein sources were BDDGS, RDDGS, WDDGS, BDDG, BDS or SBM. In a second trial BDDGS and BDDG were compared with the same feeds treated prior to cooking with cellulase enzyme. The diets, consisting of barley and distillers feed, were fortified with L-lysine and DL-methionine to achieve levels of $13.0 \%$ DCP, $0.80 \%$ lysine and $0.56 \% \mathrm{~S}$ amino acids. The distillery by-products contained crude protein $24.8-41.5 \%$, crude fat 6.3-9.5 \%, crude fibre 7.1-10.3\%, ADF 18.2-22.9 \%, NDF $33.3-43.7 \%$ and ADL $8.7-11.3 \%$ on a dry basis. Their lysine content was $0.43-1.36 \%$ of DM and their S amino acid content $0.58-1.36 \%$. The digestibilities of organic matter and crude protein were $56-83$ and 56-79 \%. DDGS from rye had low digestibilities and barley distillers solubles high. The cellulase treatment decreased the $\mathrm{OM}$ and $\mathrm{CP}$ digestibilities by $6.4-10.4$ and $15.3-15.4 \%$ units, respectively. FU/ $\mathrm{kg} \mathrm{DM}$ varied from 0.63 to 0.84 and DCP from 177 to $405 \mathrm{~g} / \mathrm{FU}$. The $\mathrm{N}$ retention of the BDDGS, RDDGS, WDDGS, BDDG, BDS and SBM diets was, respectively, 21.7, 21.1, 24.2, 23.0, 17.7 and $24.6 \mathrm{~g} / \mathrm{d}(\mathrm{P}<0.01)$ and the biological values were 55, $60,59,56,55$ and 66 . The daily gains varied from 700 to $762 \mathrm{~g}$. The data indicated that distillery by-products could replace soybean meal quite satisfactorily as a protein source in amino acid-fortified diets.
\end{abstract}

Index words: Distillery by-products, distillers dried grain with solubles, protein source, pig nutrition

\section{Introduction}

The desire to increase the domestic protein supply for animal feeding in Finland has prompted a search for alternatives to imported protein. The distillery by-products left after the alcohol process are rich in protein. When used for pigs, however, distillery feeds from the traditional ethanol process have been found to have a relatively low nutritive value (Alaviuhkola 1978, Salo 1978, Näsı 1984 c), due to their denatured protein and high fibre content.

A new ethanol plant due to start operating 
soon will use barley as raw material and employ an integrated ethanol-starch process. In this process different grain fractions are obtained and they can be combined in different ways and subjected to different treatments (LeHMUSSAARI 1984). The increased supply of distillery feed fractions expected in the next few years suggested the present study to evaluate these products, especially those derived from barley, since little information is available regarding utilization of this protein source in pig diets.

\section{Materials and methods}

Dehulled barley derived distillers feedstuffs and corresponding material derived from rye and wheat were obtained from the Koskenkorva factory of ALKO Ltd. In the second trial barley distillers feed treated with cellulase prior to cooking was compared with untreated material. The ethanol process was traditional one, comprising cooking, saccharification, fermentation and distillation. The products used in the present trial were dehydrated in a drum dryer except the solubles which were in semisolid form. The experimental diets were formulated to contain $13 \%$ DCP, $0.80 \%$ lysine and $0.56 \%$ sulphur amino acids from barley meal and respective distillery feed by fortifying the diets with Llysine $\mathrm{HCl}$ and DL-methionine. The control diets were barley soybean meal mixture and barley fortified with lysine and methionine. The protein digestibility coefficients used in formulating the diets were 0.78 for barley, 0.65 for the various distillery feeds and 0.90 for soybean meal.

The distillery feeds used in the present study were (abbreviations in parentheses):

\footnotetext{
Barley distillers dried grains with solubles (BDDGS) Rye distillers dried grains with solubles (RDDGS) Wheat distillers dried grains with solubles (WDDGS) Barley distillers dried grains (BDDG)

Barley distillers solubles (BDS)

BDDGS coming from the process using cellulase (BDDGSC)

BDDG coming from the process using cellulase (BDDGC)
}

The diets used in the digestibility trials were as follows (in percentages):

Experiment 1.

$\begin{array}{llcccc} & & \text { DDG/S } & \text { Barley } & \text { L-lys } & \text { DL-meth. } \\ \text { Diet } & \text { 1 BDDGS } & 40.0 & 60.0 & 0.20 & 0.01 \\ \text { Diet } & \text { 2 RDDGS } & 39.5 & 60.5 & 0.38 & 0.0 \\ \text { Diet } & \text { 3 WDDGS } & 27.7 & 72.3 & 0.39 & 0.0 \\ \text { Diet } & \text { 4 } \text { BDDG } & 28.3 & 71.7 & 0.11 & 0.0 \\ \text { Diet } & \text { 5 BDS } & 61.0 & 39.0 & 0.21 & 0.0 \\ \text { Diet } & \text { 6 SBM } & 14.4 & 85.6 & - & - \\ \text { Diet } & \text { 7 } 0 \text { OCONT } & & 100.0 & 0.36 & 0.13\end{array}$

\section{Experiment 2.}

$\begin{array}{llllll}\text { Diet 8 BDDGS } & 38.8 & 61.2 & 0.20 & 0.01 \\ \text { Diet 9 BDDG } & 27.5 & 67.5 & 0.12 & 0.0 \\ \text { Diet 10 BDDGSC } & 36.9 & 63.1 & 0.34 & 0.01 \\ \text { Diet 11 BDDGC } & 32.4 & 67.6 & 0.21 & 0.0\end{array}$

Eleven digestibility and balance trials were conducted using 6-day adaptation periods and 6 -day collection periods in a $6 \times 6$ Latin square design in trial 1 and $4 \times 4$ in trial 2 . The pigs were kept in metal metabolism units equipped with collection trays for separate total collection of faeces and urine. The details of the procedures and analyses are the same as described by NÄSı (1984 a, c).

\section{Results and discussion}

During the ethanol process, the starch is fermented and the other grain components concentrated. The dehydrated distillery products had a crude protein content of 33.6 to $41.5 \%$, the protein content of the condensed solubles being lower, $24.8 \%$ of DM (Table 1). The distillers feed had a crude fat content of $6.3-9.5 \%$ of DM. The fibre contents of the BDDGS and BDDG were only two-thirds of that of distillers products from whole barley (NÄsı 1984 b). Dehulling of the barley is desirable from the nutritional point of view, since the highly lignified fibre of the hulls (SAlo and Kotilainen 1970) decreases the feed value of distillers feed, and the dehulled material is easier to process (LeHMUSSAARI 1984). The acid detergent lignin content was high in the present distillery feeds as well, $9-11 \%$, possibly being partly composed of products of the Maillard reaction. 
Table 1. Chemical composition of various distillers by-products and soybean meal and barley used in digestibility experiments with pigs.

\begin{tabular}{|c|c|c|c|c|c|c|c|c|c|}
\hline & BDDGS & RDDGS & WDDGS & BDDG & BDS & BDDGSC & BDDGC & SBM & Barley \\
\hline \multicolumn{10}{|l|}{$\begin{array}{l}\text { Chemical composition, } \\
\% \text { in DM }\end{array}$} \\
\hline Dry matter & 89.9 & 92.6 & 93.6 & 95.8 & 55.4 & 96.1 & 97.4 & 88.7 & 88.3 \\
\hline Ash & 5.5 & 6.2 & 3.8 & 3.3 & 13.9 & 7.7 & 5.2 & 6.2 & 2.8 \\
\hline Crude protein & 34.4 & 33.6 & 41.5 & 40.0 & 24.8 & 33.2 & 35.4 & 50.9 & 12.3 \\
\hline True protein & 29.0 & 26.0 & 34.7 & 34.6 & 14.9 & 25.5 & 29.0 & 45.9 & 9.9 \\
\hline Ether extract & 8.4 & 6.7 & 6.3 & 7.5 & 6.5 & 9.4 & 9.5 & 1.6 & 2.4 \\
\hline Crude fibre & 7.8 & 8.4 & 9.9 & 10.2 & 1.4 & 7.1 & 10.3 & 6.9 & 6.0 \\
\hline NFE & 43.9 & 45.1 & 38.5 & 39.1 & 53.5 & 42.7 & 39.6 & 34.5 & 76.5 \\
\hline Sugars & 2.4 & 1.2 & 2.8 & 0.6 & 2.0 & 1.6 & 0.9 & - & - \\
\hline Neutral deterg. fibre & 38.0 & 37.3 & 40.9 & 47.6 & - & 33.3 & 43.7 & 11.9 & 25.2 \\
\hline Acid detergent fibre & 22.0 & 18.5 & 18.2 & 22.2 & - & 21.4 & 22.9 & 8.0 & 6.7 \\
\hline Acid detergent lignin & 9.6 & 10.6 & 8.7 & 8.9 & - & 11.3 & 9.1 & 0.8 & 1.3 \\
\hline $\begin{array}{l}\text { Pepsin- } \mathrm{HCl} \text { solubility } \\
\text { of crude protein, } \%\end{array}$ & 74.0 & 69.5 & 80.0 & 80.0 & 84.2 & 65.3 & 68.2 & 92.9 & 90.6 \\
\hline \multicolumn{10}{|l|}{ Amino acids, $\mathrm{g} / \mathrm{kg}$} \\
\hline Alanine & 14.3 & 13.5 & 14.7 & 17.7 & 6.3 & 13.2 & 14.8 & 21.4 & 5.0 \\
\hline Arginine & 13.0 & 10.5 & 13.2 & 18.1 & 4.3 & 11.3 & 15.1 & 37.0 & 5.8 \\
\hline Aspartic acid & 20.8 & 19.6 & 20.5 & 26.2 & 7.0 & 19.5 & 20.6 & 54.6 & 7.1 \\
\hline Cystine & 4.9 & 5.5 & 6.8 & 7.4 & 2.0 & 5.5 & 6.9 & 6.6 & 2.7 \\
\hline Glutamic acid & 69.4 & 69.7 & 96.0 & 87.8 & 28.1 & 69.5 & 81.9 & 88.0 & 24.5 \\
\hline Glycine & 12.7 & 12.7 & 13.8 & 15.4 & 6.5 & 12.9 & 13.4 & 20.6 & 4.9 \\
\hline Histidine & 5.8 & 5.1 & 6.7 & 7.6 & 2.5 & 5.4 & 6.4 & 12.4 & 2.4 \\
\hline Isoleucine & 11.8 & 10.5 & 13.3 & 16.0 & 3.7 & 11.5 & 14.0 & 21.0 & 3.6 \\
\hline Leucine & 23.6 & 20.2 & 26.3 & 32.1 & 7.3 & 23.2 & 27.9 & 37.4 & 8.1 \\
\hline Lysine & 8.5 & 4.0 & 5.9 & 13.0 & 3.8 & 5.4 & 9.0 & 29.6 & 4.3 \\
\hline Methionine & 3.0 & 3.1 & 2.8 & 5.6 & 1.2 & 2.1 & 4.1 & 4.2 & 1.5 \\
\hline Phenylalanine & 16.1 & 13.9 & 17.3 & 22.0 & 4.6 & 15.6 & 19.5 & 24.0 & 5.2 \\
\hline Proline & 34.3 & 28.6 & 36.8 & 47.6 & 11.2 & 33.8 & 43.2 & 26.1 & 11.6 \\
\hline Serine & 14.8 & 14.1 & 18.0 & 18.5 & 6.0 & 14.1 & 16.1 & 26.3 & 5.1 \\
\hline Threonine & 12.0 & 11.0 & 12.0 & 14.9 & 4.8 & 11.8 & 12.8 & 19.5 & 4.2 \\
\hline Tyrosine & 9.5 & 7.9 & 10.9 & 13.6 & 4.1 & 9.2 & 10.6 & 16.2 & 3.4 \\
\hline Valine & 16.9 & 14.4 & 16.5 & 22.1 & 5.5 & 14.4 & 17.5 & 21.5 & 5.5 \\
\hline Available lysine & 6.4 & 1.3 & 3.4 & 10.8 & 2.3 & 2.6 & 6.6 & 28.3 & 4.1 \\
\hline \multicolumn{10}{|l|}{ Mineral composition } \\
\hline $\mathrm{Ca} \mathrm{g} / \mathrm{kg} \mathrm{DM}$ & 1.23 & 1.47 & 1.16 & 0.92 & 1.62 & 1.06 & 0.78 & 2.14 & 0.55 \\
\hline$P \mathrm{~g} / \mathrm{kg} \mathrm{DM}$ & 7.04 & 7.63 & 6.73 & 4.27 & 15.59 & 9.58 & 6.62 & 6.71 & 4.20 \\
\hline $\mathrm{Mg} \mathrm{g} / \mathrm{kg} \mathrm{DM}$ & 2.19 & 2.29 & 2.10 & 1.02 & 5.40 & 2.89 & 1.85 & 2.63 & 1.08 \\
\hline $\mathrm{K} \mathrm{g} / \mathrm{kg} \mathrm{DM}$ & 8.87 & 9.17 & 7.94 & 3.93 & 25.18 & 13.16 & 8.28 & 22.56 & 6.28 \\
\hline $\mathrm{Na} \mathrm{g/kg} \mathrm{DM}$ & 7.42 & 10.29 & 2.79 & 4.30 & 23.77 & 11.91 & 6.57 & 0.26 & 0 \\
\hline $\mathrm{Fe} \mathrm{mg/kg} \mathrm{DM}$ & 111 & 116 & 92 & 80 & 149 & 84 & 78 & 127 & 79 \\
\hline Cu $\mathrm{mg} / \mathrm{kg} \mathrm{DM}$ & 18.4 & 13.7 & 11.0 & 21.6 & 11.1 & 16.7 & 19.5 & 16.4 & 7.6 \\
\hline $\mathrm{Zn} \mathrm{mg/kg} \mathrm{DM}$ & 115 & 60 & 73 & 83 & 81 & 58 & 48 & 49 & 58 \\
\hline $\mathrm{Mn} \mathrm{mg/kg} \mathrm{DM}$ & 56 & 61 & 66 & 25 & 69 & 39 & 27 & 41 & 21 \\
\hline
\end{tabular}

The lysine content $(0.4-1.3 \%)$ of the products and its availability $(0.33-0.83)$ were higher than in previous experiments with distillers feeds from whole barley (NÄsı 1983 c) or with those from wheat (SALo 1978). With BDDG the values for lysine, $\mathrm{S}$ amino acids and threonine were $3.4,3.4$ and $3.9 \mathrm{~g} / 16 \mathrm{~g} \mathrm{~N}$, respectively, and the availability of lysine was 0.83 , values only slightly lower than those for the raw material, barley. Wheat, corn and barley DDG have been found to have amino acid profiles fairly similar to those of the original grains (Satterlee et al. 1976, Newman and Gras 1983), but in distillers feed from rye 
Table 2. Digestibility coefficients of nutrients of barley diets containing distillery products and soybean meal as protein sources.

\begin{tabular}{|c|c|c|c|c|c|c|c|}
\hline \multicolumn{8}{|l|}{ Experiment 1} \\
\hline Diet no & 1 & 2 & 3 & 4 & 5 & 6 & $\begin{array}{c}7 \\
\text { Barley }\end{array}$ \\
\hline Prot. source & BDDGS & RDDGS & WDDGS & BDDG & BDS & SBM & Barley \\
\hline Dry matter & $74.9^{\text {bf }}$ & $71.2^{\mathrm{cg}}$ & $76.1^{\text {bf }}$ & $75.8^{\mathrm{bf}}$ & $81.5^{\text {ae }}$ & $81.9^{\mathrm{ae}}$ & 81.7 \\
\hline Ash & $51.9 \mathrm{cfg}$ & $53.7^{\mathrm{bfg}}$ & $50.4^{\mathrm{fg} g}$ & $49.1^{18}$ & $70.4^{\text {ae }}$ & $53.9^{\mathrm{br}}$ & 49.6 \\
\hline Organic matter & $76.4^{\mathrm{br}}$ & $72.4^{\mathrm{cg}}$ & $77.5^{\mathrm{bf}}$ & $77.3^{\mathrm{br}}$ & $83.0^{\mathrm{ae}}$ & $83.6^{\mathrm{ae}}$ & 83.4 \\
\hline Crude protein & $72.0^{f 8}$ & $63.6^{\mathrm{ch}}$ & $75.2^{\mathrm{br}}$ & $76.9^{\text {bef }}$ & $66.0^{\mathrm{csh}}$ & $82.3^{\mathrm{cg}}$ & 78.4 \\
\hline Ether extract & $85.0^{\text {ae }}$ & $74.6^{\text {bcfg }}$ & $79.8^{\mathrm{abfg}}$ & $80.9^{\text {abef }}$ & $82.1^{\text {ac }}$ & $72.0<8$ & 71.3 \\
\hline Crude fibre & $24.4^{\text {br }}$ & $27.0^{\text {bf }}$ & $26.9^{\mathrm{br}}$ & $26.1^{\mathrm{bf}}$ & $35.4^{\mathrm{ac}}$ & $29.0^{\text {bef }}$ & 25.9 \\
\hline NFE & $82.7 \mathrm{cg}$ & $80.1^{\text {dh }}$ & $83.6^{\mathrm{cg}}$ & $82.9 \mathrm{cs}$ & $91.0^{\mathrm{ae}}$ & $88.9^{\text {bf }}$ & 89.0 \\
\hline
\end{tabular}

Means with different letters were significantly different: $\mathrm{a}-\mathrm{d}(\mathrm{P}<0.05), \mathrm{e}-\mathrm{h}(\mathrm{P}<0.01)$.

\begin{tabular}{|c|c|c|c|c|}
\hline \\
\hline \multirow{2}{*}{$\begin{array}{l}\text { Diet no } \\
\text { Prot. source }\end{array}$} & 8 & 9 & 10 & 11 \\
\hline & BDDGS & BDDG & BDDGSC & BDDGC \\
\hline Dry matter & $76.5^{\text {cf }}$ & $77.4^{\mathrm{cf}}$ & $74.2^{\mathrm{be}}$ & $73.1^{\text {ae }}$ \\
\hline Ash & $50.5^{\mathrm{br}}$ & $46.1^{\text {ae }}$ & $53.8^{\mathrm{cg}}$ & $46.3^{\mathrm{ac}}$ \\
\hline Organic matter & $78.0^{\text {bf }}$ & $78.9^{\mathrm{br}}$ & $75.7^{\mathrm{be}}$ & $74.6^{\mathrm{ac}}$ \\
\hline Crude protein & $74.1^{\mathrm{cfg}}$ & $78.8^{\mathrm{dg}}$ & $64.5^{\text {ac }}$ & $69.5^{\text {bef }}$ \\
\hline Ether extract & $87.4^{b}$ & $84.4^{a}$ & $86.7^{\mathrm{ab}}$ & $86.2^{\mathrm{ab}}$ \\
\hline Crude fibre & $29.4^{\text {bef }}$ & $31.7 \mathrm{br}$ & $22.6^{\mathrm{ac}}$ & $23.6^{\text {aef }}$ \\
\hline NFE & $83.6^{\mathrm{bf}}$ & $83.7^{\text {br }}$ & $83.7^{b f}$ & $81.2^{\mathrm{ae}}$ \\
\hline
\end{tabular}

Means with different letters were significantly different: $a-d(P<0.05), e-g(P<0.01)$.

(RDDGS) the lysine content and availability were low. The protein quality and its deterioration are evidently closely connected with the drying method and conditions. The pepsin$\mathrm{HCl}$ solubility of the protein varied from 65 to $84 \%$ in the samples, indicating no serious denaturation in drying (Table 1). The use of cellulase in the process decreased the availability of lysine $(10-27 \%)$ and the protein solubility (9-12\% units).

The organic matter and NFE digestibilities of BDS exceeded those of the other products (P< $<.01), 83$ vs. $63-65 \%$ for $\mathrm{OM}$ and 93 vs. 54-66 for NFE, but RDDGS had lower digestibilities $(\mathrm{P}<0.01)$. In BDS and RDDGS the crude protein was less digestible $(\mathrm{P}<0.01)$ than in the other distillers byproducts (Table 3 ).

The crude protein digestibilities of BDDG and WDDGS $(73-76 \%)$ are quite promising and close to the value of barley protein (78 \%). Erixon and Pettersson (1982) con- cluded from a digestibility trial with piglets that in wheat DDG organic matter was $10 \%$ less digestible than in barley, but CP digestibility was of the same magnitude as in barley and removing the bran from DDGS increased the digestibility of both OM and CP.

The cellulase treatment in the ethanol process decreased organic matter digestibility by $6-10 \%$ units and that of crude protein by $15 \%$ units. This was evidently due to the cellulase increasing the content of reducing sugars, which reacted with amino acids and in the drying process formed Maillard reaction products, which are in largely unavailable.

The digestibilities and calculated feed values were considerably higher than those of whole barley distillers feeds (NÄsı 1984 c). The FU values of $0.75-0.79$ per $\mathrm{kg}$ DM (Table 3 ) are sufficiently high for inclusion in pig feed formulas at the level of $10-20 \%$. However, an evaluation should also be made with produc- 
Table 3. Digestibility coefficients of nutrients of distillery by-products and their calculated feed values.

\begin{tabular}{|c|c|c|c|c|c|c|c|}
\hline \multicolumn{8}{|l|}{ Experiment 1} \\
\hline & BDDGS & RDDGS & WDDGS & BDDG & BDS & SBM & Barley \\
\hline \multicolumn{8}{|l|}{ Digestibilities, \% } \\
\hline Dry matter & $64.4^{f}$ & $55.2^{f}$ & $61.8^{f}$ & $61.7^{f}$ & $81.4^{e}$ & $83.1^{e}$ & 81.7 \\
\hline Ash & $55.8^{e}$ & $59.9^{e}$ & $53.2^{f}$ & $46.4^{f}$ & $77.6^{e}$ & $76.9^{\circ}$ & 49.6 \\
\hline Organic matter & $65.7^{r}$ & 55.78 & $62.9^{\mathrm{fg}}$ & $63.0^{f g}$ & $82.8^{e}$ & $84.6^{e}$ & 83.4 \\
\hline Crude protein & $68.7^{\mathrm{fg}}$ & $55.6^{\mathrm{h}}$ & $72.8^{\mathrm{fg}}$ & $75.9^{f}$ & $62.6^{\text {eh }}$ & $87.5^{e}$ & 78.4 \\
\hline Ether extract & $90.7^{\mathrm{a}}$ & $76.3^{a}$ & $87.6^{a}$ & $87.9^{a}$ & $84.3^{\mathrm{a}}$ & $78.3^{\mathrm{a}}$ & 71.3 \\
\hline Crude fibre & $22.7^{f}$ & $28.1^{f}$ & $28.3^{r}$ & $26.4^{f}$ & $58.7^{e}$ & $44.8^{\text {ef }}$ & 25.9 \\
\hline NFE & $66.3^{r}$ & $57.9 \mathrm{~g}$ & $57.1^{8}$ & 54.38 & $92.6^{e}$ & $87.9^{e}$ & 89.0 \\
\hline \multicolumn{8}{|l|}{ Feed values } \\
\hline $\mathrm{FU} / \mathrm{kg} \mathrm{DM}$ & 0.795 & 0.652 & 0.745 & 0.763 & 0.877 & 1.041 & 1.120 \\
\hline $\mathrm{kg} / \mathrm{FU}$ & 1.401 & 1.656 & 1.435 & 1.368 & 2.062 & 1.083 & 1.018 \\
\hline DCP in DM, \% & 23.6 & 18.7 & 30.2 & 30.3 & 15.5 & 44.5 & 9.2 \\
\hline $\mathrm{DCP} / \mathrm{FU}, \mathrm{g}$ & 297 & 286 & 405 & 397 & 177 & 428 & 82 \\
\hline ME, MJ/kg DM (Just) & 13.25 & 10.81 & 12.81 & 13.10 & 14.04 & 15.71 & 14.65 \\
\hline $\mathrm{NE}, \mathrm{MJ} / \mathrm{kg} \mathrm{DM} \quad "$ & 8.06 & 6.23 & 7.73 & 7.95 & 8.65 & 9.90 & 9.11 \\
\hline NE, FU/kg DM $\quad "$ & 1.044 & 0.807 & 1.001 & 1.030 & 1.120 & 1.282 & 1.180 \\
\hline ME, MJ/kg DM (Axelss.) & 12.46 & 10.19 & 11.92 & 12.18 & 13.51 & 14.66 & 14.36 \\
\hline
\end{tabular}

Means with different letters were significantly different: $\mathrm{a}-\mathrm{d}(\mathrm{P}<0.05), \mathrm{e}-\mathrm{h}(\mathrm{P}<0.01)$.

\begin{tabular}{|c|c|c|c|c|}
\hline Experiment 2 & & & & \\
\hline & BDDGS & BDDG & BDDGSC & BDDGC \\
\hline Digestibilities, $\%$ & & & & \\
\hline Dry matter & $68.1^{\mathrm{c}}$ & $66.7 \mathrm{cfg}$ & $62.3^{\mathrm{bf}}$ & $56.4^{\text {ae }}$ \\
\hline Ash & $51.9^{\text {bef }}$ & 32.7 ae & $58.6^{\mathrm{cf}}$ & $39.8^{\text {abef }}$ \\
\hline Organic matter & $69.3^{\mathrm{ce}}$ & $67.9 \mathrm{cs}$ & $62.9^{\mathrm{bf}}$ & $57.5^{\mathrm{ae}}$ \\
\hline Crude protein & $71.8^{\mathrm{cfg}}$ & $79.0^{\mathrm{dg}}$ & $56.4^{\text {ae }}$ & $63.7^{\text {bef }}$ \\
\hline Ether extract & $94.5^{\mathrm{a}}$ & $94.6^{a}$ & $92.8^{\mathrm{a}}$ & $93.3^{\mathrm{a}}$ \\
\hline Crude fibre & $33.5^{\text {bef }}$ & $39.9 \mathrm{ft}$ & $18.2^{\text {ae }}$ & $21.1^{\text {abef }}$ \\
\hline $\mathrm{NFE}$ & $68.9^{\mathrm{cf}}$ & $58.5^{\text {be }}$ & $68.8^{\mathrm{cf}}$ & $52.8^{\mathrm{ae}}$ \\
\hline Feed values & & & & \\
\hline $\mathrm{FU} / \mathrm{kg} \mathrm{DM}$ & 0.837 & 0.823 & 0.765 & 0.725 \\
\hline $\mathrm{kg} / \mathrm{FU}$ & 1.330 & 1.267 & 1.361 & 1.416 \\
\hline DCP in DM, \% & 24.7 & 31.6 & 18.7 & 22.5 \\
\hline $\mathrm{DCP} / \mathrm{FU}, \mathrm{g}$ & 295 & 383 & 244 & 311 \\
\hline ME, MJ/kg DM (Just) & 13.95 & 14.08 & 12.57 & 12.71 \\
\hline $\mathrm{NE}, \mathrm{MJ} / \mathrm{kg} \mathrm{DM} \quad "$ & 8.58 & 8.68 & 7.55 & 7.25 \\
\hline NE, FU/kg DM " & 1.111 & 1.124 & 0.978 & 0.939 \\
\hline ME, MJ/kg DM (Axelss.) & 13.10 & 13.08 & 11.86 & 11.34 \\
\hline
\end{tabular}

Means with different letters were significantly different: $\mathrm{a}-\mathrm{d}(\mathrm{P}<0.05), \mathrm{e}-\mathrm{g}(\mathrm{P}<0.01)$.

tion trials. In growing pig diets, SBM was replaced by BDDG up to $10 \%$ and by WDDGS up to $9 \%$ without any effect on the daily gain (Erixon and Pettersson 1982, Newman and Gras 1983). The feed values are in agreement with those presented by SALO (1978) and Salo et al. (1982), but Erixon and PettersSON (1982) found higher values for wheat DDGS.
The BDDG and WDDGS diets fortified with amino acids gave $\mathrm{N}$ retentions similar to that of the SBM diet $(P>0.05)$, but the BDDGS, RDDGS and BDS diets gave poorer results ( $\mathrm{P}<0.01)$. Although this was intended, the absorbed nitrogen intake was not exactly the same, because the pigs did not eat all the ration and the protein digestibility coefficient 0.65 was not valid in every case. The 
Table 4. Nitrogen balance and protein utilization of diets containing distillery by-products and soybean meal as protein sources.

\begin{tabular}{|c|c|c|c|c|c|c|c|}
\hline \multicolumn{8}{|l|}{ Experiment 1} \\
\hline Diet no & 1 & 2 & 3 & 4 & 5 & 6 & 7 \\
\hline Prot. source & BDDGS & RDDGS & WDDGS & BDDG & BDS & SBM & Barley \\
\hline Nitrogen intake, $\mathrm{g} / \mathrm{d}$ & $62.9^{\text {ae }}$ & $63.4^{\text {ae }}$ & $62.5^{\text {abe }}$ & $61.5^{\text {abe }}$ & $58.3^{\text {be }}$ & $51.4^{\mathrm{ef}}$ & 37.9 \\
\hline $\mathrm{N}$ excreted in faeces & $17.3^{\mathrm{fg}}$ & $22.7 \mathrm{e}$ & $15.4^{\mathrm{fg}}$ & $13.9^{\mathrm{gh}}$ & $20.0^{\text {ef }}$ & $8.9^{h}$ & 7.8 \\
\hline $\mathrm{N}$ absorbed, $\mathrm{g} / \mathrm{d}$ & $45.6^{\text {ef }}$ & $40.7^{8 h}$ & $47.1^{\mathrm{e}}$ & $47.6^{\mathrm{e}}$ & $38.3^{\text {h }}$ & $42.5^{\mathrm{fg}}$ & 30.0 \\
\hline Apparent $\mathrm{N}$ digest. $\%$ & $72.0^{\mathrm{fg}}$ & $63.6^{\mathrm{ch}}$ & $75.2^{\mathrm{bf}}$ & $76.9^{\text {bef }}$ & $66.0^{\mathrm{cgh}}$ & $82.3^{\mathrm{cg}}$ & 78.4 \\
\hline $\mathrm{N}$ excreted in urine & $23.9^{a}$ & $19.6^{\mathrm{a}}$ & $22.9^{\mathrm{a}}$ & $24.6^{\mathrm{a}}$ & $20.6^{a}$ & $17.9^{\mathrm{a}}$ & 11.2 \\
\hline $\mathrm{N}$ retained, $\mathrm{g} / \mathrm{d}$ & $21.7^{\mathrm{fg}}$ & $21.1^{8}$ & $24.2^{\text {ef }}$ & $23.0^{\mathrm{efg}}$ & $17.7^{\mathrm{h}}$ & $24.6^{e}$ & 18.8 \\
\hline$-\%$ of intake & $34.3^{\text {fgh }}$ & $33.1^{\mathrm{gh}}$ & $38.8^{f}$ & $37.4^{f 8}$ & $30.5^{h}$ & $47.9^{e}$ & 49.2 \\
\hline$-\%$ of absorption & $47.8^{\text {fe }}$ & $52.0^{f}$ & $51.7^{r}$ & $48.7^{\mathrm{fe}}$ & $46.2^{e}$ & $58.3^{\mathrm{e}}$ & 62.7 \\
\hline$-\mathrm{g} / \mathrm{kg} \mathrm{W}^{0.75}$ & $1.01^{\mathrm{fg}}$ & $0.99^{\mathrm{hg}}$ & $1.14^{\mathrm{ef}}$ & $1.08^{\mathrm{efg}}$ & $0.84^{h}$ & $1.16^{\mathrm{e}}$ & 0.80 \\
\hline Urea excreted $\mathrm{g} / \mathrm{d}$ & $47.6^{e}$ & $32.5^{f g}$ & $44.0^{\text {ef }}$ & $43.5^{\text {ef }}$ & $28.0^{\mathrm{g}}$ & $31.6^{f g}$ & 14.5 \\
\hline$-\mathrm{g} / \mathrm{kg} \mathrm{W}^{0.75}$ & $2.18^{e}$ & $1.50^{f g}$ & $2.02^{\text {ef }}$ & $2.00^{\text {ef }}$ & $1.31^{8}$ & $1.44 \mathrm{~g}$ & 0.57 \\
\hline Biological value & $55.1^{8}$ & $60.0^{f}$ & $58.6^{\mathrm{fg}}$ & $55.7^{\mathrm{ig}}$ & 54.78 & $65.5^{e}$ & 73.0 \\
\hline Daily gain, g/d & $742^{a}$ & $741^{\mathrm{a}}$ & $700^{\mathrm{a}}$ & $732^{a}$ & $700^{2}$ & $762^{a}$ & 542 \\
\hline
\end{tabular}

Means with different letters were significantly different: $\mathrm{a}-\mathrm{d}(\mathrm{P}<0.05), \mathrm{e}-\mathrm{h}(\mathrm{P}<0.01)$.

\begin{tabular}{|c|c|c|c|c|}
\hline \multicolumn{5}{|l|}{ Experiment 2} \\
\hline Diet no & 8 & 9 & 10 & 11 \\
\hline Prot. source & BDDGS & BDDG & BDDGSC & BDDGC \\
\hline Nitrogen intake, $\mathrm{g} / \mathrm{d}$ & $84.3^{e}$ & $82.4^{f}$ & $84.7^{\mathrm{d}}$ & $82.1^{8}$ \\
\hline $\mathrm{N}$ excreted in faeces & $21.8^{\mathrm{de}}$ & $17.4^{e}$ & $30.1^{f}$ & $25.1^{\mathrm{d}}$ \\
\hline $\mathrm{N}$ absorbed, $\mathrm{g} / \mathrm{d}$ & $62.5^{\mathrm{c}}$ & $65.0^{\circ}$ & $54.6^{\mathrm{d}}$ & $57.0^{d}$ \\
\hline Apparent $\mathrm{N}$ digest. $\%$ & $74.1^{\mathrm{cfg}}$ & $78.8^{\mathrm{d} g}$ & $64.5^{\text {ae }}$ & $69.5^{\text {bef }}$ \\
\hline $\mathrm{N}$ excreted in urine & $37.2^{\mathrm{ab}}$ & $38.2^{\mathrm{b}}$ & $28.6^{c}$ & $31.6^{\mathrm{bc}}$ \\
\hline $\mathrm{N}$ retained, $\mathrm{g} / \mathrm{d}$ & $25.3^{\mathrm{a}}$ & $26.8^{a}$ & $26.0^{\mathrm{a}}$ & $25.4^{\mathrm{a}}$ \\
\hline - $\%$ of intake & $30.0^{\mathrm{a}}$ & $32.7^{a}$ & $30.8^{a}$ & $30.9^{\mathrm{a}}$ \\
\hline - $\%$ of absorption & $40.5^{\mathrm{a}}$ & $41.6^{a}$ & $48.0^{=}$ & $44.5^{\mathrm{a}}$ \\
\hline$-\mathrm{g} / \mathrm{kg} \mathrm{W}^{0.75}$ & $0.79^{a}$ & $0.84^{a}$ & $0.81^{a}$ & $0.82^{a}$ \\
\hline Urea excreted g/d & $66.1^{d}$ & $63.9 \mathrm{dr}$ & $45.5^{\mathrm{e}}$ & $54.5^{\mathrm{de}}$ \\
\hline Biological value & $48.6^{\mathrm{a}}$ & $49.5^{a}$ & $56.8^{\mathrm{a}}$ & $52.9^{\mathrm{a}}$ \\
\hline
\end{tabular}

Means with different letters were significantly different: $\mathrm{a}-\mathrm{c}(\mathrm{P}<0.05), \mathrm{d}-\mathrm{g}(\mathrm{P}<0.01)$.

urea excretion on the RDDGS and BDS diets was low and at the same level as on the SBM diet, but the other diets had significantly higher values $(\mathrm{P}<0.01)$. The biological values of the diets including distillery products were significantly lower than those of the SBM-barley diet $(\mathrm{P}<0.01)$ (Table 4$)$.

The results of Newman and Gras (1983) indicated that apparent nitrogen retention was not affected when BDDG replaced SBM, composing up to $20 \%$ of the diet. THONG et al. (1978) measured nitrogen retention in gilts and found no differences between diets in which DDGS and SBM were used as protein supplements. NÄsı (1984 c), however, found that nitrogen retention on a WDS diet was similar to that on the control diet, but was reduced on the diets with BDDGS or BDS, due to the lower amount of protein absorbed and especially the lower lysine intake. With WDDGS diets SALo (1978) recorded low nitrogen retention $(10-12 \mathrm{~g} / \mathrm{d})$, when DDGS was used as sole protein supplement. Here, the daily gains of $700-742 \mathrm{~g}$ for the pigs on barley-distillery product diets were satisfactory compared with the value of $762 \mathrm{~g} / \mathrm{d}$ for the pigs fed on SBM-barley, and higher than for the pigs on the barley amino acid supplemented diet, $542 \mathrm{~g}$.

The present experiment performed to assess 
the nutritive value of barley distillers byproducts indicated that the products obtained from dehulled barley are similar in feed value to products derived from the wheat. According to the $\mathrm{N}$-balance results, distillers byproducts fortified with lysine and sulphur amino acids could replace SBM quite satisfactorily, but further production experiments are needed. In a feeding trial with laying hens in which SBM was replaced with BDDGS and WDDGS at level of $10-20 \%$ in diet fortified with lysine ans sulphur amino acids the performance of the birds on the test diets was similar to that of the controls (Näsı 1985).
Although it has many technical advantages, the cellulase treatment in the ethanol process decreases the nutritive value of distillers feeds, at least in the process in which distillers solubles are dried with distillers grains. It would thus be desirable to investigate alternative processing methods. This study gives some data that deserve consideration in planning the integrated starch-ethanol process. The many feed fractions yielded by the process can be treated and combined in different ways to provide suitable feeds for domestic animals, including monogastrics.

- 1985. Distillers feeds from barley and wheat as protein source for laying hens. To be published.

SALO, M-L. 1978. Vehnärankkijauhon rehuarvo lihasikojen ruokinnassa. J. Scient. Agric. Soc. Finl. 50: 291-295.

- \& Kotilainen, K. 1970. On the carbohydrate composition and nutritive value of some cereals. J. Scient. Agric. Soc. Finl. 42: 21-29.

-, TUORI, M. \& KIISKINEN, T. 1982. Rehutaulukot ja ruokintanormit. Helsinki. 70 p.

Satterlee, L.D., Vavak, D.M., Abdul-Kadir, R. \& KENDRIK, J.G. 1976. The chemical, functional and nutritional characterization of protein concentrates from distillers grains. Cer. Chem. 53: 739-749.

Thong, L.A., Jensen, A.H., Harmon, B.G. \& CorneLuUs, S.G. 1978. Distillers grains with solubles as a supplemental protein source in diets for gestating swine. J. Anim. Sci. 46: 674-677.

Ms received September 30, 1985

\section{SELOSTUS}

\section{Eri viljoista saadut rankkirehut lihasikojen ruokinnassa}

\section{Matti Näsi}

Helsingin yliopisto, kotieläintieteen laitos, $00710 \mathrm{Helsin} k i$

Sulavuus- ja tasekokeissa tutkittiin kuoritusta ohrasta saatujen rankkirehujen sekä venhä- ja ruisrankin rehuarvoa ja valkuaisen hyväksikäyttöă kasvavilla lihasioilla sekä prosessiteknisistä syistä lisätyn sellulaasientsyymin vaikutusta ohrarankkirehuihin. Kuivattujen rankkien raakavalkuaispitoisuus oli $34-42 \%$ ja ohrarankkiuutteen 
$25 \%$ : ka:ssa. Ohrarankkien kuitupitoisuudet olivat puolta pienempiä kuin koko-ohrarankeissa. Lysiinipitoisuudet olivat korkeampia kuin aikaisemmin saadut tulokset. Eri rankkirehut olivat yksinomaisena valkuaistăydennyksenă aminohappotasapainotetuissa dieeteissä, joissa srvpitoisuus oli $13 \%$, lysiiniä $0.80 \%$ ja rikkipitoisia aminohappoja $0.56 \%$. Eri rankkien orgaaninen aine suli $56-83 \%$ ja raakavalkuainen $56-76 \%$. Energia-arvoksi saatiin $0.65-0.88 \mathrm{ry} / \mathrm{kg}$ ka eri rankkirehuille ja srv oli $177-405 \mathrm{~g} /$ ry. Ruisrankki oli muita rankkirehuja huonommin sulavaa. Sellulaasikäsittely alensi ohrarankkire- hun sulavuutta ja rehuarvoa. Typen pidättyminen aminohapoilla tảydennetyillă ohra- ja vehnärankkidieteillä oli samanlaista kuin soijadieetillä, $23-24$ vs. $24.6 \mathrm{~g} / \mathrm{d}$. Valkuaisen hyvăksikāyttö rankkirehuja sisältävillä dieteillä oli alempi kuin soijadieetillä. Kuoritusta ohrasta saadut rankkirehut olivat vehnärankin kanssa samanarvoisia. Aminohapoilla tåydennettyjă rankkirehuja voitaisiin tasekokeen tulosten perusteella käyttää sikojen rehuna, joskin kasvatuskokeissa on selvitettävä näiden rehujen tuotantovaikutus. 